\title{
Decontamination methods utilising house hold practices for removing pesticides on field bean for food safety
}

\begin{abstract}
Field and laboratory experiments were conducted during Rainy season 2015 (from July to October) to study the decontamination of different pesticides on field bean. The highest removal of all insecticides from green pods of field bean were obtained from the treatment Formula 1 (4\% Acetic Acid $+0.1 \% \mathrm{NaHCO}_{3}+1$ Lemon) ranging from 67.60 to 74.90 per cent followed by the use of $2 \%$ salt solution in reducing the residues of the pesticides chlorantraniliprole 20\% SC @ 30g a.i ha ${ }^{-1}$, bifenthrin 10\% EC @ 812g a.i ha ${ }^{-1}$ profenophos 50\% EC@400g a.i ha ${ }^{-1}$, lambda cyhalothrin 5\% SC @ 15.63g a.i ha ${ }^{-1}$, beta cyfluthrin (Solomon 300 OD) @ 30g a.i ha ${ }^{-1}$ Baking soda solution $(0.1 \%$ ) was found more effective than 2\% salt solution for the removal of fipronil 5\% SC @ 500g a.i ha ${ }^{-1}$, flubendiamide 480 \% SC@60g a.i ha-1 imidacloprid (Solomon 300 OD) @, 30g a.i ha ${ }^{-1}$. Tap water wash was the least effective method in the removal of all insecticides from green pods of field bean.
\end{abstract}

Volume 8 Issue 3 - 2018

\author{
Srinivasa Reddy S, Narendra Reddy C, Shashi \\ Vemuri, Swarupa $S$ \\ Department of Entomology, College of Agriculture, India
}

Correspondence: Shashi Vemuri, Department of Entomology, College of Agriculture, Pjtsau, Rajendranagar, Hyderabad, Pin code 500 030, India,

Email srinivasreddyagri@gmail.com, sash_3156@yahoo.co.in

Received: November 13, 2017 | Published: June 07, 2018

Keywords: green pods, field bean, removal of pesticides, insecticides, leguminosae

\section{Introduction}

Field bean belongs to the family Leguminosae, is an important pulse cum vegetable crop in India and is cultivated extensively for its fresh tender pods, leaves and seeds and as cattle feed. In India this is grown mostly in Andhra Pradesh, Karnataka, Tamil Nadu, Kerala and Assam and the fresh and dried seeds constitute major vegetarian source of proteins in the diet and are rich in nutritive value and are rich source of carbohydrates, minerals, vitamins, such as vitamin A, vitamin C, fat and fiber. The protein content of field bean is quite high varying from 20.0 to 28.0 per cent. ${ }^{1}$ However the primary cause attributed for lower yields of field bean is due to the heavy infestation of an array of pest complex. Govindan ${ }^{2}$ recorded as many as 55 species of insects and a species of mite feeding on the crop from seedling stage to the harvest of the crop in Karnataka and considered the pod borers as important as they cause $80-100$ per cent loss. ${ }^{3}$ Naik et al., ${ }^{4}$ reported Pod borers as key impediments for the low productivity causing a loss of 54 per cent in field beans.). The major yield loss is inflicted by the pod feeders which include both the pod borers and pod bugs. Pesticide use has increased rapidly over the last two decades at the rate of 12 per cent per year and the extensive, irrational use of pesticides resulted in the presence of residues of insecticides on different edible plant parts resulting in various public health problems and ill effects on environment. The increasing amount of pesticide residues in vegetables is a major concern to the consumers as the insecticides leave residues on pods which may persist up to harvest. Effecting export and sometimes rejection of consignments. Hence, great significance has to be given to for safe consumption. As the pods are consumed as vegetable, the pest control should be with pesticides having low residues. Vegetables retain residues of cocktail of chemicals as they are applied at different stages of crop growth and often prior to harvest resulting in health hazards to the customers. Removal of these pesticide residues is of importance before consumption of vegetables, Various studies have shown that processing leads to large reduction of residues in the prepared food, particularly through washing, peeling and cooking operation..$^{5-7}$ Therefore, it is essential to look for cheap and effective methods which can be implemented easily at home. Thus keeping this requirement in mind, the present studies were taken up to evaluate the effect of different household processing and lab practices to reduce pesticide residues to a safe level for human consumption.

\section{Materials and methods}

\section{Evaluation of decontamination methods for removal of pesticide residues}

The evaluation of decontamination methods for the removal of pesticide residues was carried out by collecting zero day samples after spray from the field trial during Rainy season of 2015 from different treatments at $12 \mathrm{kgs}$ and made into six sets and replicated four times. One set of sample from each treatment was analyzed for initial deposits of the pesticide and remaining sets of samples of zero days from each treatment were subjected to various decontamination methods separately and these samples were analyzed for residues through validated methods. Finally the residues were calculated to know the efficiency of the various decontamination methods in the removal of pesticide residues from the field bean samples. The following decontamination / risk mitigation methods were selected for evaluation of efficiency in removal of pesticide residues from field bean.

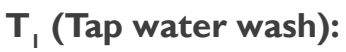

Four liters of tap water was taken into the plastic tub of 7liters capacity and $2 \mathrm{~kg}$ of field bean pods were dipped in the tub for $10 \mathrm{~min}$, followed by the tap water wash for 30sec, further the pods were kept for air drying on tissue paper for $5 \mathrm{~min}$.

\section{$T_{2}$ (Soaking in $2 \%$ salt solution for 10 min followed by tap water wash):}

Four liters of $2 \%$ salt solution was prepared by mixing $80 \mathrm{~g}$ of table salt in 4 liters of water in plastic tub of 7liters capacity and $2 \mathrm{~kg}$ field bean pods were dipped in the tub for $10 \mathrm{~min}$, followed by the tap water 
wash for $30 \mathrm{sec}$, further the pods were kept for air drying on tissue paper for $5 \mathrm{~min}$, followed by analysis.

\section{$T_{3}$ (Cooking in pressure cooker for $10 \mathrm{~min}$ ):}

Cooking of the $2 \mathrm{~kg}$ field bean pods in pressure cooker for $10 \mathrm{~min}$, followed by the tap water wash for $30 \mathrm{sec}$, further the pods were kept for air drying on tissue paper for $5 \mathrm{~min}$, followed by analysis.

\section{$\mathbf{T}_{4}$ (Dipping in $\mathbf{0 . 1} \%$ sodium bicarbonate solution keep it for $10 \mathrm{~min}$ followed by tap water wash):}

Four liters of $0.1 \%$ of $\mathrm{NaHCO}_{3}$ solution was prepared by mixing of $4 \mathrm{~g}$ of $\mathrm{NaHCO}_{3}$ in 4 liters of water in plastic tub of 7liters capacity, mixture was kept for $1 \mathrm{~min}$ and $2 \mathrm{~kg}$ of field bean pods were dipped in the tub for $10 \mathrm{~min}$, followed by the tap water wash for $30 \mathrm{sec}$, further the pods were kept for air drying on tissue paper for $5 \mathrm{~min}$, followed by analysis.

\section{$T_{5}$ (Dipping in Formula I (4\% Acetic Acid + $0.1 \%$ NAHCO3 + I Lemon)}

Four liters of Formula 1 was prepared by mixing $160 \mathrm{ml}$ of acetic acid (Vinegar), 4grams of sodium bicarbonate and 4 lemons added to 4 liters of water in plastic tub of 7 liters capacity, mixture was kept for $1 \mathrm{~min}$ and $2 \mathrm{~kg}$ field bean pods were dipped in the tub for $10 \mathrm{~min}$, followed by the tap water wash for $30 \mathrm{sec}$, further the pods were kept for air drying on tissue paper for $5 \mathrm{~min}$, followed by analysis.
Per cent removal of pesticide:

Per cent removal $=\frac{\text { Initial deposit }- \text { Residues after treatment }}{\text { Initial dep }} \times 100$

\section{Extraction and clean -up}

By using robot coupe blixer $5 \mathrm{~kg}$ beans were homogenized and $15 \pm 0.1 \mathrm{~g}$ sample of it was collected in $50 \mathrm{ml}$ centrifuge tube. Fortification was done using standard (CRM to which acetonitrile $(30 \pm 0.1 \mathrm{ml})$ was added. using Heidolph silent crusher .homogenization was done for $2-3$ minutes at $14000-15000 \mathrm{rpm}$. To this material sodium chloride $3 \pm 0.1 \mathrm{~g}$ was added and shaken gently and to separate the organic layer at $2500-3000 \mathrm{rpm}$ Centrifuged for $3 \mathrm{~min} .16 \mathrm{ml}$ of the top organic layer was collected in centrifuge tube of $50 \mathrm{ml}$ and the moisture content was removed adding $.9 \pm 0.1 \mathrm{~g}$ anhydrous sodium sulphate. extract $(8 \mathrm{ml})$ was transferred to $15 \mathrm{ml}$ tube having PSA sorbent $(0.4 \pm 0.01 \mathrm{~g})$ and $1.2 \pm 0.01 \mathrm{~g}$ anhydrous magnesium sulphate After vertexing for $30 \mathrm{sec}$ and centrifuging at 2500-3000 rpm $2 \mathrm{ml}$ extract of taken into test tubes and by using turbovap evaporated to dryness and made to $1 \mathrm{ml}$ with n-Hexane: Acetone (9:1) for further analysis using GC ECD (Table1).

Gas Chromatograph- of AGILENT-7890B model was utilised for estimating the Fipronil, Chlorantraniliprole, Bifenthrin, Profenophos, Lambda cyhalothrin and Beta cyfluthrin residues utilising ECD whereas Liquid chormatograph Shimadzu make LC-30 with Mass Spectrometer (MS) mass detector was utilised for Flubendamide and Imidacloprid analysis (Table 2).

Table I Details of GC parameters

\begin{tabular}{|c|c|}
\hline Gas Chromatograph & Gas Chromatography- AGILENT- 7890B \\
\hline Column & $\begin{array}{l}\text { VF- } 5 \mathrm{~ms} \text { Capillary Column } 30 \mathrm{~m} \text { length, } 0.25 \mathrm{~mm} \text { Internal Diameter, } 0.25 \mathrm{~mm} \text { film thickness; } 1 \% \\
\text { methyl siloxane }\end{array}$ \\
\hline \multirow[t]{6}{*}{ Column Oven $\left({ }^{\circ} \mathrm{C}\right)$} & $\begin{array}{l}\text { Fipronil- Initial } 180^{\circ} \mathrm{C} \text { - } 2 \text { min hold - increase @ } 10^{\circ} \mathrm{C} / \mathrm{min} \text { upto } 260^{\circ} \mathrm{C} \text { - hold time } 5 \text { mins - increase } \\
\text { @ } 2^{\circ} \mathrm{C} / \text { min upto } 280^{\circ} \mathrm{C} \text { - hold for } 10 \text { min. }\end{array}$ \\
\hline & Chlorantraniliprole - Initial $180^{\circ} \mathrm{C}$ for $2 \mathrm{~min}$ - increase @ $10^{\circ} \mathrm{C} / \mathrm{min}$ upto $260^{\circ} \mathrm{C}$ - hold for $15 \mathrm{~min}$. \\
\hline & Bifenthrin - Initial $200^{\circ} \mathrm{C}$ for $6 \mathrm{~min}$ - increase @ $20^{\circ} \mathrm{C} / \mathrm{min}$ upto $280^{\circ} \mathrm{C}$ - hold for $10 \mathrm{~min}$. \\
\hline & Profenophos - Initial $150^{\circ} \mathrm{C}$ for $1 \mathrm{~min}$ - increase @ $20^{\circ} \mathrm{C} / \mathrm{min}$ upto $250^{\circ} \mathrm{C}$ - hold for $9 \mathrm{~min}$. \\
\hline & Lambda cyhalothrin - Initial $200^{\circ} \mathrm{C}$ for $6 \mathrm{~min}$ - increase @ $20^{\circ} \mathrm{C} / \mathrm{min}$ upto $280^{\circ} \mathrm{C}$ - hold for $10 \mathrm{~min}$. \\
\hline & $\begin{array}{l}\text { Beta cyfluthrin - Initial } 180^{\circ} \mathrm{C} \text { - } 2 \mathrm{~min} \text { hold - increase } @ 10^{\circ} \mathrm{C} / \mathrm{min} \text { upto } 260^{\circ} \mathrm{C} \text { - hold time } 5 \mathrm{~min}- \\
\text { increase } @ 2^{\circ} \mathrm{C} \text { /min upto } 280^{\circ} \mathrm{C} \text { - hold for } 10 \mathrm{~min} .\end{array}$ \\
\hline Detectors & Electron Capture Detector (ECD) \\
\hline $\begin{array}{l}\text { Detector } \\
\text { Temperature }\left({ }^{\circ} \mathrm{C}\right)\end{array}$ & 300 \\
\hline $\begin{array}{l}\text { Injector Temperature } \\
\left({ }^{\circ} \mathrm{C}\right)\end{array}$ & 280 \\
\hline Injector Status & Split Ratio: $1: 2$ \\
\hline Carrier Gas & Nitrogen, Iolar II, Purity 99.999\% \\
\hline $\begin{array}{l}\text { Carrier Gas Flow } \\
\left.(\mathrm{ml} \mathrm{min})^{-1}\right)\end{array}$ & 2 \\
\hline $\begin{array}{l}\text { Make-up Flow (ml } \\
\left.\min ^{-1}\right)\end{array}$ & 25 \\
\hline Retention time (min) & Fipronil 8.96 \\
\hline
\end{tabular}




\author{
Chlorantraniliprole 4.18 \\ Bifenthrin 11.94 \\ Profenophos 11.87 \\ Lambda cyhalothrin 9.11 \\ Beta cyfluthrin 19.74 \\ Chlorantraniliprole 25.00 \\ Bifenthrin 20.00 \\ Profenophos 15.00 \\ Lamda cyhalothrin 20.00 \\ Beta cyfluthrin 35.00
}

Total run time (min) Fipronil 35.00

Table 2 Details of HPLC operating parameters

\begin{tabular}{|c|c|c|c|}
\hline HPLC & \multicolumn{3}{|l|}{ SHIMADZU LC-30 } \\
\hline Detector & \multicolumn{3}{|l|}{ Mass Spectrometer (MS) } \\
\hline Column & \multicolumn{3}{|c|}{ HPLC Column Kinetex $\mathrm{Cl} 8$ column, 2.6 micron particle size 100 length, $3 \mathrm{~mm}$ ID } \\
\hline Solvents in Pump A & \multicolumn{3}{|l|}{ Water } \\
\hline Solvents in Pump B & \multicolumn{3}{|l|}{ Metanol } \\
\hline Solvents Gradient Program & \multicolumn{3}{|c|}{ Water: Methanol (5:95) mixture run for $2 \mathrm{~min}$} \\
\hline Solvents Gradient rate & \multicolumn{3}{|l|}{$0.4 \mathrm{mlmin}^{-1}$} \\
\hline Quantity of sample injected & \multicolumn{3}{|l|}{$|\mu|$} \\
\hline Run time & \multicolumn{3}{|l|}{$10 \mathrm{~min}$} \\
\hline \multirow[t]{2}{*}{ Retention time } & \multicolumn{3}{|l|}{ Flubendamide-7.92min } \\
\hline & \multicolumn{3}{|l|}{ Imidacloprid- $2.29 \mathrm{~min}$} \\
\hline \multirow[t]{7}{*}{ LC Program For flubendamide } & Time & Methanol & Water \\
\hline & 0.01 & 35 & 65 \\
\hline & 2 & 60 & 40 \\
\hline & 4 & 80 & 20 \\
\hline & 6 & 60 & 40 \\
\hline & 8 & 35 & 65 \\
\hline & 10.01 & Stop & - \\
\hline \multirow[t]{3}{*}{ LC Program for imidacloprid } & Time & Methanol & Water \\
\hline & 0.01 & 35 & 65 \\
\hline & 4 & Stop & - \\
\hline
\end{tabular}




\section{Results and discussion}

Evaluation of decontamination methods for removal of pesticide residues from Dolichos bean:

The field bean pod samples collected at zero day (2hours after application) after spray from the plots treated with fipronil 5\% SC@500g a.i. ha ${ }^{-1}$,flubendamide 480\% SC @ 60g a.i ha ${ }^{-1}$, chlorantraniliprole 20\% SC@30g a.i. ha ${ }^{-1}$, bifenthrin 10 EC @ 812g a.i ha ${ }^{-1}$, profenophos 50\% EC @ 400g a.i. ha ${ }^{-1}$, lambda cyhalothrin 5\% SC@15.63g a.i ha ${ }^{-1}$, imidacloprid 17.8\% SL @ 25g a.i. ha ${ }^{-1}$ and imidacloprid + beta cyfluthrin 300 OD @ 30g a.i.ha ${ }^{-1}$ to estimate the initial deposits and efficiency of different decontamination methods through quantification of their residues after subjecting to risk mitigation methods, and the results are presented in (Table 3) (Figures $1-9)$.

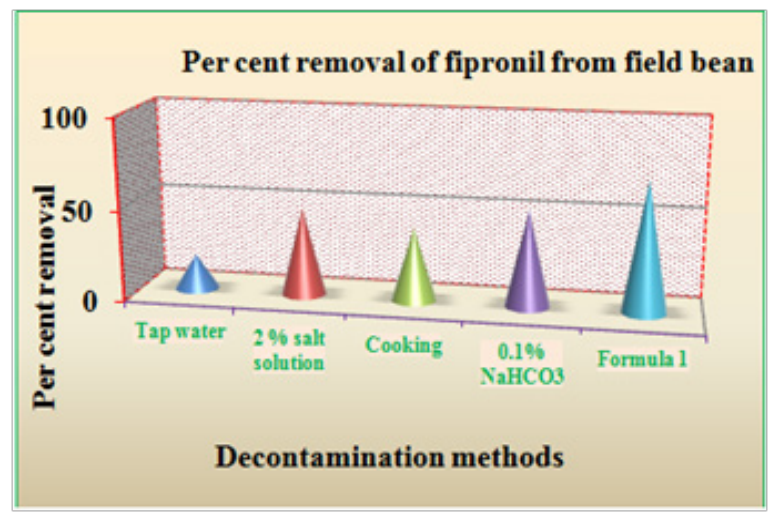

Figure I Per cent removal of fipronil residues.

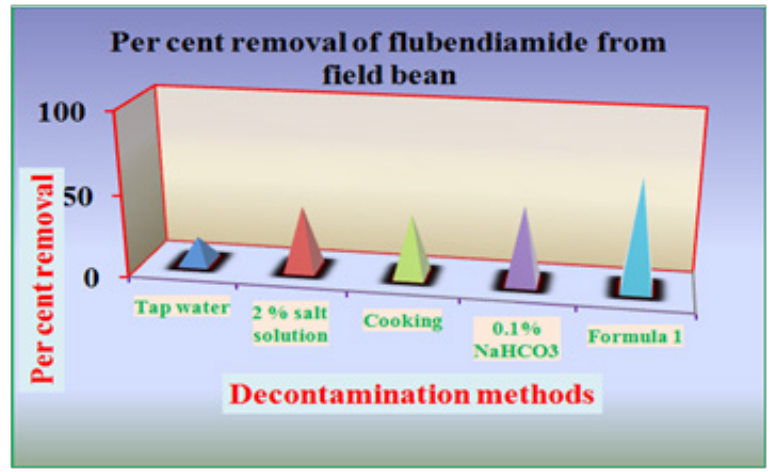

Figure 2 Per cent removal of flubendiamide residues.

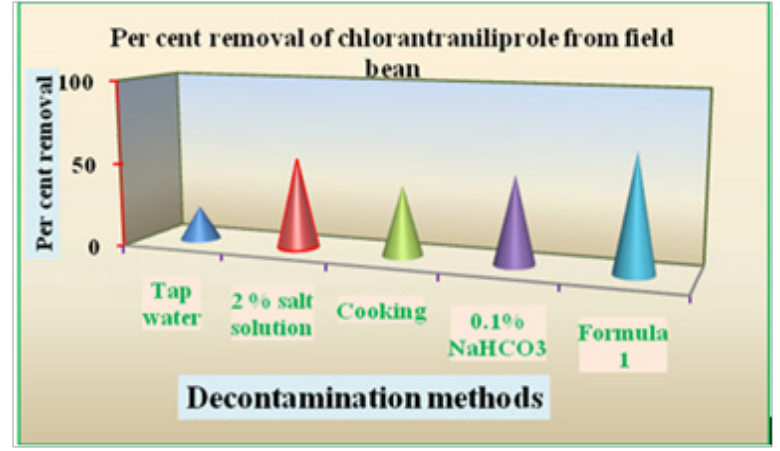

Figure 3 Per cent removal of chlorantraniliprole residues.

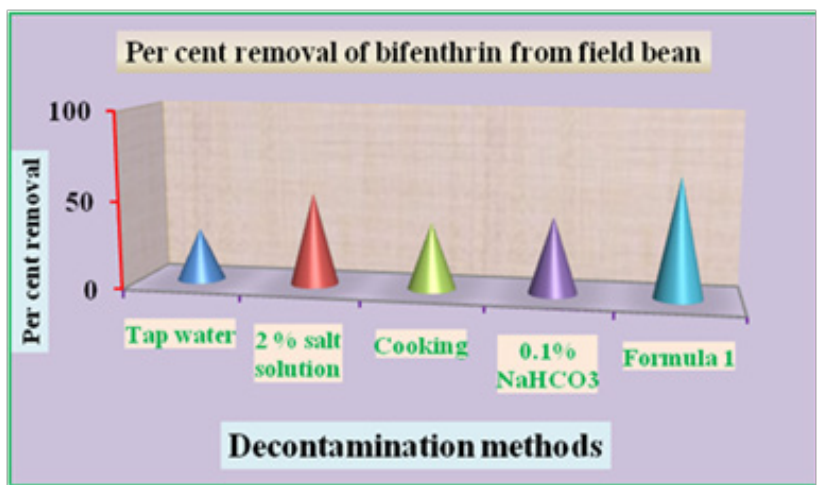

Figure 4 Per cent removal of bifenthrin residues.

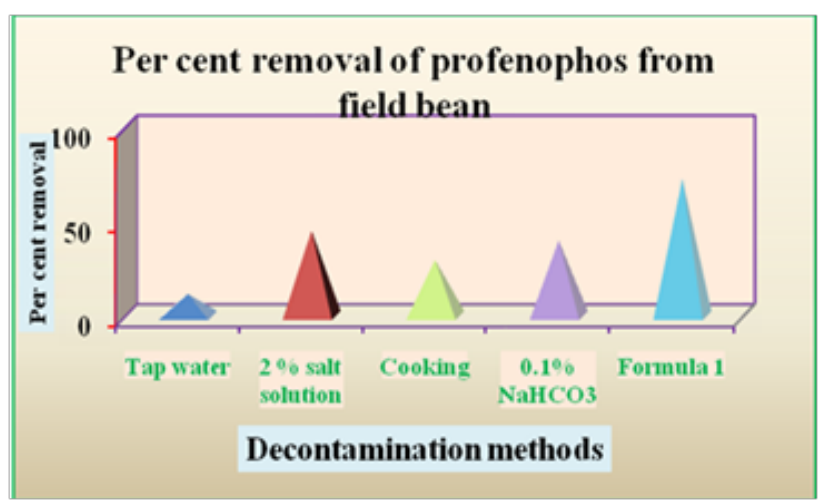

Figure 5 Per cent removal of profenophos residues.

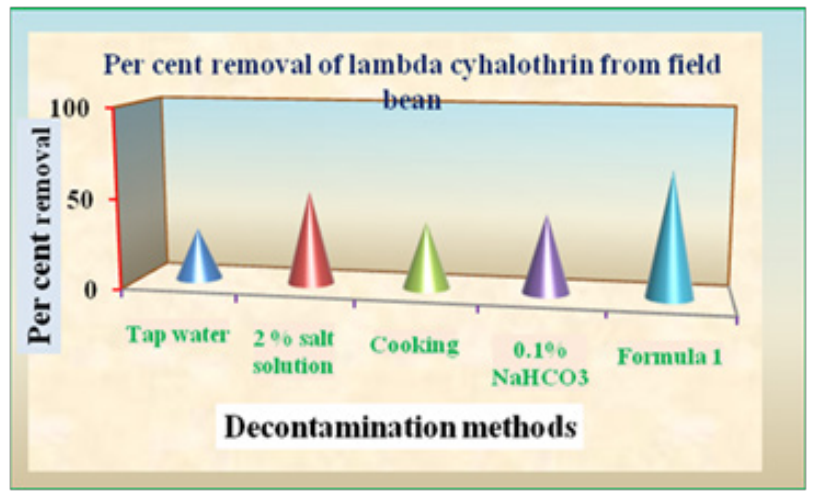

Figure 6 Per cent removal of lambda cyhalothrin residues.

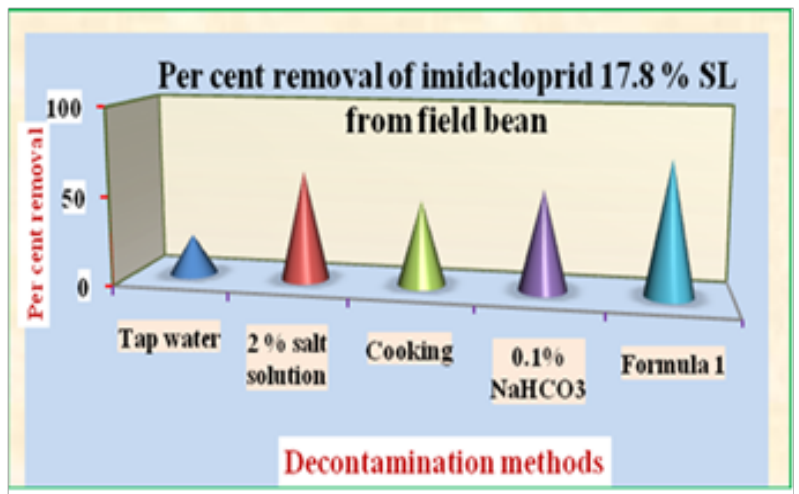

Figure 7 Per cent removal of imidacloprid I7.8\% SL residues. 


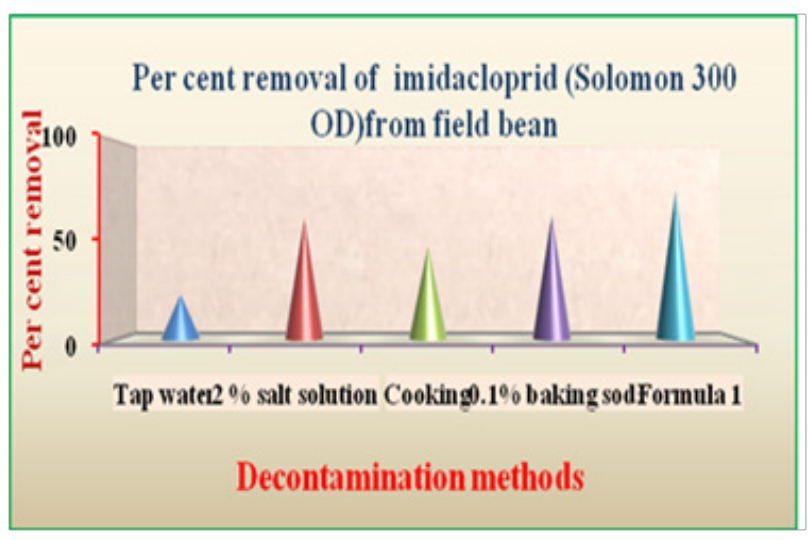

Figure 8 Per cent removal of imidacloprid residues.

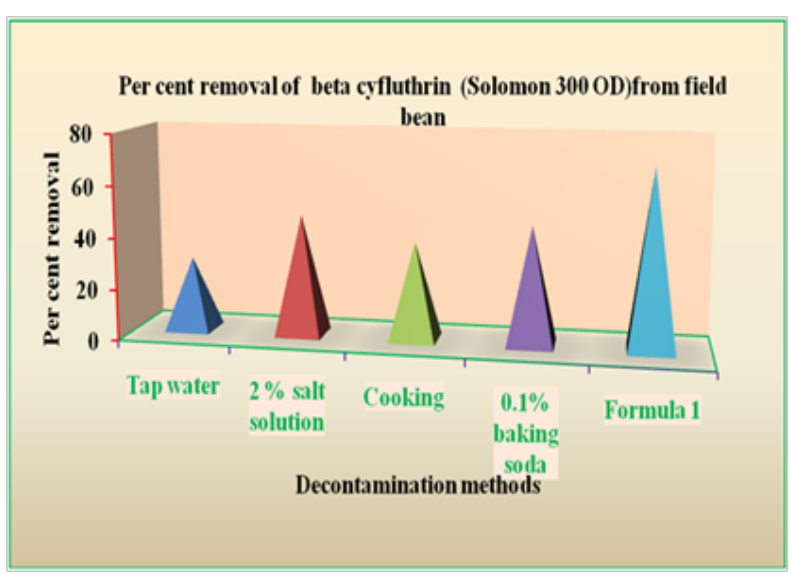

Figure 9 Per cent removal of betacyfluthrin (Solomon 3000D) residues from field bean by various decontamination methods.

\section{Fipronil 5\% SC @ 500g a.i. ha-1}

Fipronil is a broad-use insecticide that belongs to the phenylpyrazole chemical family. Dipping of field bean pods in formula 1 solution for $10 \mathrm{~min}$ followed by tap water wash for $30 \mathrm{sec}$ was found to be significantly effective $(71.18 \%)$ in removal of insecticides than other decontamination methods. The percentage removal of fipronil residues due to various decontamination methods in descending order were, formula $1(71.18 \%)>$ dipping in $0.1 \%$ baking soda solution $(52.51 \%)>$ soaking in $2 \%$ salt solution $(48.25 \%)>$ cooking in pressure cooker $(39.88 \%)>$ washing with tap water $(18.96 \%)$. Per cent removal of fipronil residues on field bean pods from various decontamination methods is shown in Figure1.

\section{Flubendamide 480\% SC @ 60g a.i ha ${ }^{-1}$}

Flubendiamide is a novel class of insecticide belonging to thalic acid diamides family. Various decontamination methods were evaluated in order to know their efficiency in removing of flubendamide residues from field bean pods. Dipping in formula 1 solution for $10 \mathrm{~min}$ followed by tap water wash for $30 \mathrm{sec}$ was found to be significantly effective $(66.90 \%)$ than other treatments. The next promising treatment was dipping in $0.1 \%$ baking soda solution for $10 \mathrm{~min}$ followed by tap water wash for $30 \mathrm{sec}(46.37 \%)$. The next best treatments were soaking in $2 \%$ salt solution followed by tap water wash for $30 \mathrm{sec}(38.81 \%)$ and cooking in pressure cooker for $10 \mathrm{~min}$ followed by tap water wash for $30 \sec (37.49 \%)$ while tap water wash for $10 \mathrm{~min}(15.61 \%)$ was found to be least effective in removal of flubendiamide residues from field bean pods. Per cent removal of flubendamide residues due to various decontamination methods is presented in Figure 2.

\section{Chlorantraniliprole 20\% SC @ 30 g a.i. ha-1}

Chlorantraniliprole is a new class of selective insecticides belonging to anthranilic diamides family. The field bean pod samples obtained from the plots sprayed thrice with chlorantraniliprole $20 \%$ SC @ 30g a.i ha ${ }^{-1}$ were subjected to various decontamination methods. The results indicated that among the different treatments employed, dipping of field bean pods in formula 1 solution for $10 \mathrm{~min}$ followed by tap water wash for $30 \mathrm{sec}$ was found to be significantly effective (68.28\%) than other treatments. Soaking in $2 \%$ salt solution for $10 \mathrm{~min}$ followed by tap water wash for $30 \sec (52.93 \%)$ was found to be next promising treatment, followed by dipping in $0.1 \%$ baking soda solution for $10 \mathrm{~min}$ followed by tap water wash for $30 \mathrm{sec}(51.65 \%)$, cooking in pressure cooker for $10 \mathrm{~min}$ followed by tap water wash for $30 \mathrm{sec}(41.50 \%)$ and tap water wash for $10 \mathrm{~min}$ (20.28\%). Per cent removal of chlorantraniliprole residues from various decontamination methods are presented in Figure 3.

Table 3 Decontamination of insecticides using different methods

\begin{tabular}{|c|c|c|c|c|c|c|}
\hline \multirow[t]{2}{*}{ Insecticides } & \multicolumn{6}{|c|}{ Mean per cent removal of insecticides (\%) } \\
\hline & $\begin{array}{l}\text { Tap } \\
\text { water }\end{array}$ & $\begin{array}{l}2 \% \text { salt } \\
\text { solution }\end{array}$ & $\begin{array}{l}\text { Cooking in pressure } \\
\text { cooker }\end{array}$ & $\begin{array}{l}0.1 \% \text { baking } \\
\text { soda }\end{array}$ & $\begin{array}{l}\text { Formula } \\
\text { I }\end{array}$ & $\begin{array}{l}\text { CD } \\
(5 \%)\end{array}$ \\
\hline Fipronil 5\% SC & 18.96 & 48.25 & 39.88 & 52.51 & 71.18 & 5.38 \\
\hline Flubendiamide $480 \%$ SC & $15.6 \mid$ & 38.81 & 37.49 & 46.37 & 66.9 & 4.22 \\
\hline Chlorantraniliprole $20 \%$ SC & 20.28 & 52.93 & 41.5 & 51.65 & 68.28 & 2.82 \\
\hline Bifenthrin $10 \% \mathrm{EC}$ & 29.64 & 52.29 & 37.74 & 43.11 & 67.6 & 3.96 \\
\hline Profenophos $50 \%$ EC & 11.39 & 45.12 & 29.43 & 39.88 & 72.43 & 3.26 \\
\hline Lambda cyhalothrin 5\% SC & 28.77 & 51.96 & 36.88 & 43.63 & 68.9 & 4.03 \\
\hline Imidacloprid I7.8\% SL & 22.74 & 61.89 & 47.67 & 56.11 & 74.9 & 7.11 \\
\hline Imidacloprid (Solomon 300\% OD) & 22.38 & 61.05 & 46.87 & 62.47 & 74.29 & 3.12 \\
\hline Betacyfluthrin (Solomon 300\% OD) & 28.59 & 47.06 & 38.07 & 45.78 & 69.42 & 3.19 \\
\hline
\end{tabular}




\section{Bifenthrin I0\% EC @ 8I2g a.i ha-1}

The removal of bifenthrin residues from field bean samples were significantly differed in different decontamination methods at 2hours after spraying of bifenthrin 10\% EC @ 812g a.i ha ${ }^{-1}$. The results revealed that dipping in formula 1 solution for $10 \mathrm{~min}$ followed by tap water wash for $30 \mathrm{sec}$ was found to be significantly effective when compared to other treatments. In this treatment residues were reduced up to 67.60 per cent. The next promising treatment was soaking in $2 \%$ salt solution for $10 \mathrm{~min}$ followed by tap water wash for $30 \mathrm{sec}(52.29 \%)$ followed by dipping in $0.1 \%$ baking soda solution for $10 \mathrm{~min}$ followed by tap water wash for $30 \mathrm{sec}(43.11 \%)$, cooking in pressure cooker for $10 \mathrm{~min}$ followed by tap water wash for $30 \mathrm{sec}(37.74 \%)$ and tap water wash for $10 \min (29.64 \%)$ (Figure 4).

\section{Profenophos 50\% EC @ 400g a.i ha ${ }^{-1}$}

The field bean pod samples were collected from the plots sprayed with profenophos 50\% EC @ 400g a.i ha ${ }^{-1}$ were subjected to different decontamination methods at 2 hours after third spray. The results revealed that dipping in formula 1 solution for $10 \mathrm{~min}$ followed by tap water wash for $30 \mathrm{sec}$ was found to be significantly effective among all treatments. In this treatment residues were reduced up to 72.43 per cent. The next promising treatment was soaking in $2 \%$ salt solution for $10 \mathrm{~min}$ followed by tap water wash for $30 \mathrm{sec}(45.12 \%)$, followed by dipping in $0.1 \%$ baking soda solution for $10 \mathrm{~min}$ followed by tap water wash for $30 \mathrm{sec}(39.88 \%)$, cooking in pressure cooker for 10min followed by tap water wash for $30 \mathrm{sec}(29.43 \%)$ and tap water wash for $10 \mathrm{~min}(11.39 \%)$ (Figure 5).

\section{Lambda cyhalothrin 5\% SC @ I5.63g a.i ha-1}

The various decontamination methods were evaluated in order to know their efficiency in removing lambda cyhalothrin residues from field bean pods. The treatment with dipping in formula 1 solution for $10 \mathrm{~min}$ followed by tap water wash for $30 \mathrm{sec}$ was found to be significantly effective $(68.90 \%)$ than other treatments. The next promising treatment was soaking in $2 \%$ salt solution for $10 \mathrm{~min}$ followed by tap water wash for $30 \sec (51.96 \%)$, followed by dipping $0.1 \%$ baking soda solution for $10 \mathrm{~min}$ followed by tap water wash for $30 \mathrm{sec}(43.63 \%)$, cooking in pressure cooker for $10 \mathrm{~min}$ followed by tap water wash for $30 \mathrm{sec}(36.88 \%)$ and tap water wash for $10 \mathrm{~min}$ (28.77\%) (Figure 6).

\section{Imidacloprid I7.8\% SL @ 25g a.i. ha-1}

The collected field bean green pod samples were subjected to different decontamination solutions at 2 hours after spraying. The results depicted that dipping in formula 1 solution for $10 \mathrm{~min}$ followed by tap water wash for $30 \mathrm{sec}$ was found to be significantly effective in removing 74.90 per cent residues, than other treatments. The next promising treatment was soaking in $2 \%$ salt solution for $10 \mathrm{~min}$ followed by tap water wash for $30 \mathrm{sec}(61.89 \%)$, followed by dipping in $0.1 \%$ baking soda solution for $10 \mathrm{~min}$ followed by tap water wash for $30 \mathrm{sec}(56.11 \%)$, cooking in pressure cooker for $10 \mathrm{~min}$ followed by tap water wash for $30 \mathrm{sec}(47.67 \%)$ and tap water for $10 \mathrm{~min}$ (22.74\%) (Figure 7).

\section{Imidacloprid + Beta cyfluthrin 300 OD @ 30g a.i. ha-1 Imidacloprid (Solomon 300 OD)}

The collected field bean green pod samples were subjected to different decontamination solutions at 2 hours after third spray. The results depicted that dipping in formula 1 solution for 10min followed by tap water wash for $30 \mathrm{sec}$ was found to be significantly effective in removing 74.29 per cent residues, than other treatments. The next promising treatment was dipping in $0.1 \%$ baking soda solution for $10 \mathrm{~min}$ followed by tap water wash for $30 \mathrm{sec}(62.47 \%)$, followed by soaking in $2 \%$ salt solution for $10 \mathrm{~min}$ followed by tap water wash for $30 \sec (61.05 \%)$, cooking in pressure cooker for $10 \mathrm{~min}$ followed by tap water wash for $30 \mathrm{sec}(46.87 \%)$ and the least effective decontamination method was tap water for $10 \mathrm{~min}(22.38 \%)$ (Figure 8$)$.

\section{Beta cyfluthrin (Solomon 300 OD)}

The field bean pod samples collected from the plots treated with imidacloprid + beta cyfluthrin@30g a.i. ha ${ }^{-1}$ were subjected to various decontamination methods. The treatment with dipping in formula 1 solution for $10 \mathrm{~min}$ followed by tap water wash for $30 \mathrm{sec}$ was found to be significantly effective $(69.42 \%)$ than other treatments. Then next promising treatment was soaking in $2 \%$ salt solution for $10 \mathrm{~min}$ followed by tap water wash for $30 \mathrm{sec}(47.06 \%)$ and the treatments followed were dipping in $0.1 \%$ baking soda for $10 \mathrm{~min}$ followed by tap water wash for $30 \mathrm{sec}(38.07 \%$ ), cooking in pressure cooker for $10 \mathrm{~min}$ followed by tap water wash for $30 \mathrm{sec}(45.78 \%)$ and tap water wash for $10 \mathrm{~min}(28.59 \%)$. (Figure 9).

To minimize dietary exposure to pesticides, it is pertinent to explore strategies that effectively help in reducing the residue content at individual level. Five simple, labour less and cost effective unit operations were imparted to field bean samples for reducing dietary consumption of pesticide residues which can be even followed in poor populace. Out of all treatments imparted each pesticide has its own treatment of reduction. In the present study, dipping in formula $1(4 \%$ Acetic Acid $+0.1 \% \mathrm{NaHCO}_{3}+1$ Lemon), a formulation prepared by AINP on Pesticide Residues proved to be the most efficient in removing various pesticides from field bean samples. Similar results were also reported by Radwan et al., ${ }^{8}$ who reported that washing of hot pepper, sweet pepper and brinjal with $2 \%$ acetic acid removed pirimophos-methyl residues by $76.61,95.74$ and 94.58 per cent, respectively.

Zhang et al., ${ }^{9}$ found that $79.8,65.8,74.0$ and 75.0 per cent residues of chlorpyriphos, cypermethrin and chlorothalonil were removed by washing cabbage with $10 \%$ acetic acid solution for $20 \mathrm{~min}$, respectively. The treatment with soaking in $2 \%$ salt solution for $10 \mathrm{~min}$ followed by tap water wash for30 sec was found to be next best decontamination method in case of chlorantraniliprole, bifenthrin, profenophos, lambda- cyhalothrin, imidacloprid and beta cyfluthrin (Solomon 300\% OD formulation). The results were in agreement with the findings of Geetha $^{10}$ who reported that loss of $31.47,32.13,46.87$ and 43.78 per cent of chlorpyriphos, profenophos, cypermethrin and triazophos residues in spinach by salt water treatment for $10 \mathrm{~min}$. Washing of brinjal with 2 per cent salt solution removed the 45.3, 43.0, 52.1, 49.8, $54.0,47.9$ and 76.5 per cent of dimethoate, chlorpyriphos, quinalphos, profenophos, phosalone, lambda-cyhalothrin and malathion residues, respectively. ${ }^{11}$

Washing of tomato fruits with $10 \%$ salt solution removed 90.80 and 82.40 per cent of dimethoate and profenophos residues. ${ }^{12}$ Washing of cucumbers in $2 \%$ salt solution for $10 \mathrm{~min}$ removed residues of trichlorfon, dimethoate, dichlorovos, fenitrothian and chlorpyriphos residues by $46.30,47.80,70.20,28.90$ and 60.50 per cent, respectively. ${ }^{13}$ 
The treatment with dipping in $0.1 \%$ baking soda $\left(\mathrm{NaHCO}_{3}\right)$ solution for $10 \mathrm{~min}$ followed by tap water wash for $30 \mathrm{sec}$ was the next best treatment in removing residues of fipronil, flubendamide and imidacloprid (Solomon 300\% OD formulation) from field beans. The results were in line with the findings of Cherukuri et al., ${ }^{11}$ who reported that dipping with 0.1 per cent sodium bicarbonate solution in brinjal removed the $25.4,21.5,34.0,29.8,33.6,30.4$ and 61.3 per cent of dimethoate, chlorpyriphos, quinalphos, profenophos, phosalone, lambda-cyhalothrin and malathion residues, respectively.

Liang et al., ${ }^{13}$ who reported that washing of cucumber with $2 \% \mathrm{NaHCO}_{3}$ was efficient to remove the trichlorfon, dimethoate, dichlorovos, fenitrothian and chlorpyriphos residues by $73.20,58.70$, $96.40,51.10$ and 77.80 per cent, respectively, while Satpathy found that tomato fruits washed with $0.1 \% \mathrm{NaHCO}_{3}$ solution removed residues of parathion, methyl parathion, malathion, fenitrothion, formothion and chlorpyriphos by $73.10,77.40,86.80,57.00,86.40$ and 87.20 per cent, respectively.

The next best decontamination method was cooking in pressure cooker for $10 \mathrm{~min}$ followed by tap water wash for $30 \mathrm{sec}$. The reports of Neha et al., ${ }^{14}$ indicated that cooking of brinjal removed the monocrotophos, quinalphos, permethrin and cypermethrin residues by $29.68,22.84,25.00$ and 40.00 per cent, respectively, while Walia found that cooking of brinjal in water removed residues of cypermethrin 41.40 per cent.

Tap water wash for $10 \mathrm{~min}$ was the least effective treatment and the findings of the present investigations were in agreement with the findings of Abou $\mathrm{Arab}^{12}$ who reported that washing of tomato fruits with water removed dimethoate and profenophos residues up to 18.80 and 22.17 per cent, respectively. Jayakrishnan et al., ${ }^{15}$ reported that washing of tomato fruits with water removed lambda cyhalothrin residues by 29-30 per cent. Washing of potatoes with water removed $30-50$ per cent of phosalone residues and 13.50 per cent of profenophos residues when washed with tap water. The tap water wash for $10 \mathrm{~min}$ removed trichlorfon, dimethoate, dichlorovos, fenitrothian and chlorpyriphos residues by $36.60,21.70,22.60,22.20$ and 59.20 per cent in cucumber, respectively. ${ }^{13}$ Gupta et al., ${ }^{16}$ also evaluated the dissipation and decontamination of imidacloprid and lambda - cyhalothrin residues in brinjal and found similar results Cherukuri et al., ${ }^{11}$ reported that the loss of $30.7,35.3$, 45.6, 42, 44.1, 40.9 and 70.3 per cent of dimethoate, chlorpyriphos, quinalphos, profenophos, phosalone, lambda-cyhalothrin and malathion residues in brinjal by tap water wash while, Pallavi et al., ${ }^{17}$ reported the loss of malathion, chlorpyriphos, quinalphos, profenophos and cypermethrin in curry leaf to an extent of 25.9, 10.8, 18.6, 21.7 and 8.2 per cent by washing with tap water for $15 \mathrm{~min}$. Similarly, tap water washes for $10 \mathrm{~min}$ removed chlorpyriphos, profenophos, cypermethrin and triazophos residues by $15.37,13.30,19.21$ and 19.88 per cent, respectively in spinach. ${ }^{10,18}$

\section{Conclusion}

The highest removal of all insecticides from green pods of field bean were obtained from the treatment Formula 1 ( 4\% Acetic Acid $+0.1 \% \mathrm{NAHCO}_{3}+1$ Lemon ) ranging from 67.60 to 74.90 per cent followed by 2\% salt solution in chlorantraniliprole 20\% SC @ 30g a.i ha $^{-1}$, bifenthrin 10\% EC@812g a.i ha ${ }^{-1}$ profenophos 50\% EC @ 400g a.i ha ${ }^{-1}$, lambda cyhalothrin 5\% SC @ 15.63g a.i ha ${ }^{-1}$, beta cyfluthrin (Solomon 300 OD) @ 30g a.i ha ${ }^{-1}$ while,0.1\% baking soda solution was found more effective than 2\% salt solution in fipronil 5\% SC @ 500g a.i ha ${ }^{-1}$, flubendiamide 480\% SC @ 60g a.i ha ${ }^{-1}$ imidacloprid (Solomon 300 OD) @, 30g a.i ha ${ }^{-1}$ and least removal of all insecticides from green pods of field bean was recorded from tap water wash which ranged from 11.39 to 29.64 per cent.

\section{Acknowledgments}

None.

\section{Conflict of interest}

Author declares no conflict of interest.

\section{References}

1. Schaaffhausen RV. Dolichos lablab or Hyacinth bean, its use for feed, food and soil improvements. Economic Botany. 1963;17:146-153.

2. Govindan, R. Insects of the field bean, Lablab purpureus var. lignosus medikus with special reference to the biology and ecology of the pod borer, Adisura atkinsoni Moore (Leipdoptera: Noctuidae). M. Sc. Thesis. University of Agricultural Sciences, Bangalore; 1974. p. 1-3.

3. Katagihallimath SS, Siddappaji C. Observations on the incidence of lepidopteran pod borers of Dolichos lablab and the results of preliminary insecticidal trials to control them. 2nd All India Congress of Zoology. 1962; 59 p.

4. Naik MI, Tejaswi L, Sridhara S, et al. Yield loss and economic injury level for pod borers of field bean (Lablab purpureus L.). Environment and Ecology. 2009;27(3):1044-1047.

5. Youssef MM, A Abdel Aal, MA Radwan, et al. Removal of pirimiphosmethyl and chlorpyrifos- methyl residues from treated tomatoes and broad beans by commercial and home preparative procedures. Alexandria Science Exchange. 1995;16:461-469.

6. Soliman KM. Changes in concentration of pesticide residues in potatoes during washing and home preparation. Food and Chemical Toxicology. 2001;39(8):887-891

7. Zohair A. Behavior of some organophosphorus and organochlorine pesticides in potatoes during soaking in different solutions. Food Additives and Contaminants. 2001;39(7):751-755.

8. Radwan MA, Shiboob MH, Abu-Elamayem MM, et al. Residues of Pirimiphos-methyl and profenofos on green pepper and eggplant fruit and their effects on some quality properties. Emirates Journal of Agriculture Sciences. 2004;16(1):32-42.

9. Zhang YS, Li XP, Liu HM, et al. Study on universal cleaning solution in removing blended pesticide residues in chinese cabbage. Journal of Environmental Chemistry and Ecotoxicology. 2013;5(8):202-207.

10. Geetha P. Survey on pesticide usage, monitoring of pesticide residues and decontamination methods in spinach (Spinacia oleracea L.). M. Sc. Thesis. PJTSAU, Rajendranagar, India; 2015.

11. Cherukuri SR, Shashi Bhushan V, Harinatha Reddy A, et al. Risk mitigation methods for removal of pesticide residues in brinjal for food safety. University Journal of Agricultural Research. 2014;2(8):279-283.

12. Abou Arab AAK, Abou Donia MA. Pesticide residues in some Egyptian spices and medicinal plants as affected by processing. Food Chemistry. 2001;72(4):439-445.

13. Liang Y, Wang W, Shen Y, et al. Effects of home preparation on organophosphorus pesticide residues in raw cucumber. Food Chemistry. 2012;133(3):636-640

14. Neha T, Joshi P, Joshi H. Effect of household processing on reduction of pesticide residues in brinjal (egg plant, Solanum melongena). Advances in Applied Science Research. 2012;3(5):2860-2865. 
15. Jayakrishnan S, Dikshit AK, Singh JP, et al. Dissipation of lambdacyhalothrin on tomato (Lycopersicon esculentum Mill.) and removal of its residues by different washing processes and steaming. Bull Environ Contam Toxicol. 2005;75(2):324-328.

16. Gupta S, Singh SP, Satyanarayana P, et al. Dissipation and decontamination of imidacloprid and lambda-cyhalothrin residues in brinjal. International Journal of Plant Protection. 2015;8(2):379-383.

17. Pallavi NK, Thomas BM, Naseema Beevi S, et al. Monitoring and decontamination of pesticide residues in okra (Abelmoschus esculentus Moench). International Journal of Interdisciplinary and Multidisciplinary Studies. 2014;1(5):242-248.

18. Khay S, Choi JH, Abd El Aty, et al. Dissipation behavior of lufenuron, benzoyl phenyl urea insecticides, in/on Chinese cabbage applied by foliar spraying under greenhouse conditions. Bull Environ Contam Toxicol. 2008;81(4):369-372. 